\title{
PENINGKATAN KEMAMPUAN PENYELESAIAN MATEMATIKA MATERI FUNGSI DAN FUNGSI INVERS MELALUI METODE THINK PAIR SHARE PADA SISWA KELAS XI-GEOMATIKA
}

\author{
Sri Bardini \\ SMK Negeri 2 Surakarta, Jl. LU.Adisucipto No 33 Surakarta \\ sri.bardini@yahoo.com
}

\begin{abstract}
Abstrak
Tujuan dalam penelitian ini secara umum adalah untuk meningkatkan kemampuan dalam pemecahan masalah Aljabar pada Fungsi dan Fungsi Invers siswa kelas XI Geomatika Sekolah Menengah Kejuruan Negeri 2 Surakarta, dan secara khusus bertujuan untuk meningkatkan hasil belajar Matematika materi Fungsi dan Fungsi Invers pada siswa kelas XI Geomatika di Sekolah Menengah Kejuruan Negeri 2 Surakarta.

Hasil penelitian dapat disimpulkan bahwa penerapan metode pembelajaran Think Pair Square Penerapan metode pembelajaran Think Pair Share secara signifikan dapat meningkatkan kemampuan siswa dalam Fungsi dan Fungsi Invers Siswa kelas XI DPIB-A SMKN 2 Surakarta. Kemampuan siswa dalam Fungsi dan Fungsi Invers pada kondisi awal sebelum tindakan persentase kemampuannya berada pada kategori rendah yaitu 47.22 $\%$ dan pada siklus I mengalami peningkatan dengan tingkat kemampuan sedang yaitu 64\% dan pada siklus II kemampuan siswa berada pada kategori tinggi yaitu $86 \%$. Peningkatan kemampuan siswa dalam pemecahan masalah matematika sangat signifikan yaitu sebesar 38,78\% dari kondisi awal.
\end{abstract}

Kata kunci: Think Pair Square (TPSq), Kemampuan siswa, Fungsi dan Fungsi Invers

\begin{abstract}
The purpose of this study in general is to improve the ability in solving Algebra problems in the Inverse Function and Function of Grade XI students of Geomatics Vocational High School 2 Surakarta, and specifically aims to improve the learning outcomes of Mathematics in the Function and Function of Inversions in class XI Geomatics students at Surakarta Vocational High School 2 Surakarta.

The results of the study concluded that the application of Think Pair Square learning methods The application of Think Pair Share learning methods could significantly improve students' abilities in the Functions and Inverse Functions of Grade XI DPIB-A students of SMKN 2 Surakarta. The ability of students in Inversion Functions and Functions in the initial conditions before the action percentage of ability is in the low category that is $47.22 \%$ and in the first cycle has increased with a moderate ability level of $64 \%$ and in the second cycle the ability of students is in the high category that is $86 \%$. Increasing the ability of students in solving mathematical problems is very significant that is equal to $38.78 \%$ of the initial conditions.
\end{abstract}

Keywords: Think Pair Square (TPSq), Student Abilities, Inverse Functions and Functions

\section{PENDAHULUAN}

Matematika sebagai salah satu mata pelajaran wajib bagi siswa pada jenjang pendidikan dasar dan menengah diperlukan penguasaan sejak dini, sehingga dapat membekali perta didik untuk meningkatkan kemampuan (kompetensi) berpikir logis, analisis, sistematis, kritis, dan kreatif serta kemampuan bekerja sama. Kompetensi tersebut diperlukan agar mereka memiliki kemampuan memperoleh, mengelola, dan memanfaatkan informasi untuk bertahan hidup pada keadaan yang selalu berubah, tidak pasti, dan kompetitif Namun demikian ternyata hasilnya belum optimal, ini ditunjukan dengan ketuntasan belajar yang masih rendah khususnya dalam kompetensi fungsi dan fungsi inver. Hasil pengamatan menunjukkan bahwa kemampuan siswa dalam memecahkan masalah aljabar khususnya pada materi fungsi dan fungsi inver masih sangat rendah yakni 47,22\% atau 17 siswa dari 36 siswa telah mampu memecahkan masalah dalam matematika sedangkan yang tidak mampu sebesar 52,7\% atau 19 siswa dari 36 siswa. Indikator dari rendahnya kemampuan pemecahan masalah aljabar tentang fungsi dan fungsi inver tersebut terlihat dalam beberapa aspek berikut : 1) siswa yang 
memahami masalah (understanding problem) sebesar 55\% atau 20 dari 36 siswa, 2) siswa yang mampu merencanakan (devising a plan), sebesar 44.44\%, atau 16 dari 36 siswa, 3) siswa yang mampu melaksanakan rencana penyelesaian masalah (carry-ingout the plan) sebesar 47\%, atau 17 dari 36 siswa, dan 4) siswa yang mampu melakukan pengecekan penyelesaian (looking back) sebesar 44\% atau 16 siswa dari 36.

Pendekatan pembelajaran yang tepat untuk mengatasi permasalahan pebelajaran di kelas XIGeomatika tersebut adalah pembelajaran saintifik, pembelajaran ini mengadopsi langkah-langkah dalam membangun pengetahuan melalui metode ilmiah yang memungkinkan terbudayakannya kecakapan berpikir sains, dan berkemampuan berpikir kreatif melalui proses kegiatan mengamati, menanya, mencoba, mengasosiasi, serta mengkomunikasikan. Salah satu metode pembelajaran yang memberikan kelima pengalaman tersebut adalah pembelajaran yang bersifat Cooperative Learning yang menarik atau menyenangkan, yang melibatkan siswa, yang dapat meningkatkan aktivitas dan tanggung jawab siswa.

Banyak model pembelajaran yang dapat diterapkan dalam proses belajar mengajar. Salah satunya adalah model pembelajaran dengan tipe "Think Pair Share" atau biasa disingkat TPS. Dalam TPS siswa melakukan tukar pengalaman dengan anggota-anggota tim lain untuk memperoleh pengetahuan masing-masing. Dengan suasana kelompok dalam pembelajaran maka diharapkan akan menarik dan menimbulkan efek rekreaktif dalam belajar siswa. Aktivitas belajar santai karena belajar dengan teman sebaya ini dirancang dalam model pembelajaran Cooperative Learning dengan tipe TPS memungkinkan siswa dapat belajar lebih rileks disamping menumbuhkan tanggung jawab, kerjasama, persaingan sehat dan keterlibatan belajar.

Berdasarkan uraian di atas, upaya tindakan kelas untuk meningkatkan kemampuan memecahkan masalah aljabar khususnya pada materi induksi matematika pada siswa XI-Geomatika di SMK Negeri 2 Surakarta di beri judul "Peningkatan Kemampuan Penyelesaian Matematika Materi Fungsi Dan Fungsi Invers Melalui Metode Think Pair Share Pada Siswa Kelas XiGeomatika Di Semester Gasal Smk Negeri 2 Surakarta Tahun Pelajaran 2018/2019.

\section{METODE}

\section{Setting Penelitian}

Penelitian dilakukan di kelas XI Geomatika SMKN 2 Surakarta. Alasan pemilihan subjek ini adalah bahwasanya siswa kelas XI Geomatika memiliki tingkat pemecahan masalah Aljabar khususnya pada materi fungsi dan fungsi inver yakni $52.7 \%$ siswa belum mampu memecahkan masalah matematika khususnya dalam materi fungsi dan fungsi inver dengan benar.

Penelitian Tindakan Kelas ini berlangsung selama 3 bulan, yaitu bulan Agustus 2018 sampai dengan Oktober 2018. Adapun rincian kegiatan penelitian dan alokasi waktunya di rinci seperti tabel berikut : 
Tabel 1.

Alokasi Waktu Penelitian

\begin{tabular}{|c|l|l|l|l|}
\hline No & Uraian Kegiatan & Agt & Sept & Okt \\
\hline 1 & Penyusunan Proposal PTK & $\mathrm{XX}$ & & \\
\hline 2 & Menyusun instrument penelitian & $\mathrm{XX}$ & & \\
\hline 3 & Pengumpulan data dengan melakukan tindakan kelas & & $\mathrm{XX}$ & $\mathrm{XX}$ \\
\hline 4 & Analisis Data & & $\mathrm{XX}$ & $\mathrm{XX}$ \\
\hline 5 & Pembahasan/Diskusi & & $\mathrm{XX}$ & $\mathrm{XX}$ \\
\hline 6 & Menyusun laporan hasil penelitian & & & $\mathrm{XX}$ \\
\hline
\end{tabular}

\section{Jenis Penelitian}

Penelitian ini merupakan penelitian tindakan (action research), karena penelitian dilakukan untuk memecahkan masalah pembelajaran di kelas. Penelitian ini termasuk penelitian deskriptif, sebab menggambarkan bagaimana suatu teknik pembelajaran diterapkan dan bagaimana hasil yang diinginkan dapat dicapai. Penelitian kelas merupakan bagian pemecahan masalah yang dimulai dari : a) perencanaan (planning), b) pelaksanaan (action), c) pengumpulan data (observasing), d) menganalisis data / informasi untuk memutuskan sejauh mana kelebihan atau kelemahan tindakan tersebut (reflecting). PTK bercirikan perbaikan terus menerus sehingga kepuasan peneliti menjadi tolak ukur berhasilnya (berhentinya) siklus-siklus tersebut.

Penelitian ini mendiskripsikan kemampuan siswa dalam pemecahan aljabar pada materi induksi matematika dengan metode Think Pair Share bagi siswa kelas XI Geomatika SMKN 2 Surakarta semester gasal tahun pelajaran 2018/2019.

\section{Teknik Pengumpulan Data}

Teknik yang digunakan untuk mengumpulkan data di atas meliputi teknik tes, teknik wawancara, dan teknik observasi, yang masing-masing diuraikan sebagai berikut :

\section{Teknik tes}

Tes menurut Sudijono (1996:66) adalah alat atau prosedur yang dipergunakan dalam rangka pengukuran dan penilaian. Tes yang diberikan siswa mencakup semua materi dalam fungsi dan fungsi inver berupa kemampuan memecahkan masalah matematika yang meliputi : 1) pemahaman masalah (understanding problem), 2) perencanaan (devising a plan), 3) pelaksanakan rencana penyelesaian masalah (carry-ingout the plan), dan 4) melakukan pengecekan penyelesaian (looking back).

Tes yang digunakan dalam penelitian ini berupa uraian. Penilaian tes ini digunakan untuk mengetahui perkembangan dan keberhasilan pelaksanaan tindakan berupa tes kemampuan dalam memecahkan masalah Aljabar.

\section{Teknik Wawancara}


Teknik wawancara yang dilakukan untuk menggali data tentang proses kemampuan dalam memecahkan masalah aljabar khususnya fungsi dan fungsi inver melalui metode Think Pair Share. Hasil wawancara didiskusikan kepada teman sejawat untuk kemudian dianalisis bersama-sama untuk mengetahui berbagai kelemahan yang ada untuk dicari solusi terhadap kelemahan-kelemahan tersebut. Teknik Observasi

Teknik observasi dilakukan untuk mengamati perkembangan pembelajaran ketrampilan membaca pemahaman melalui metode Think Pair Share yang dilakukan oleh siswa dan guru sebelum pelaksanaan tindakan, saat pelaksanaan tindakan sampai akhir tindakan.

Data yang diinginkan dari observasi ini meliputi : tindak belajar siswa dan tindak mengajar guru serta data perubahan hasil belajar yang terjadi akibat tindakan pembelajaran melalui metode Think Pair Share.

\section{Validasi Data}

Untuk menguji validasi data, peneliti menggunakan trianggulasi data, trianggulasi metode, dan trianggulasi sumber. Trianggulasi data yaitu membandingkan dan mengecek kembali derajat kepercayaan suatu informasi yang telah diperoleh melalui waktu dan alat yang berbeda. Informasi dari nara sumber yang satu dibandingkan dengan informasi dari nara sumber lainnya. Trianggulasi metode dalam penelitian tindakan ini adalah kumpulan data-data yang sejenis tetapi diambil dengan teknik yang berbeda yakni wawancara dan observasi. Tujuan dari Penggunaan metode pengumpulan data yang berbeda ini diusahakan mengarah kepada sumber data yang sama untuk menguji kemantapan informasinya. Dalam penelitian ini sumber data yang digunakan berasal dari guru kolaborator, berupa data kualitatif/non tes untuk mengevaluasi tindakan guru dan kegiatan siswa selama pembelajaran, sedangkan data data kuantitatif berupa nilai-nilai siswa selama kegiatan pembelajaran berlangsung.

\section{Prosedur Tindakan}

Jenis penelitian yang digunakan adalah penelitian tindakan kelas (Classroom Action Research) yang dilakukan oleh peneliti secara langsung. Penelitian ini berbasis kolaboratif, sehingga dalam pelaksanaannya penelitian ini melakukan kerja sama dengan teman sejawat yaitu guru bidang studi matematika. Peneliti selalu bekerjasama dengan guru teman sejawat untuk melakukan tindakan mulai dari : 1. Hasil temuan masalah; 2. perencanaan tindakan; 3. pelaksanaan tindakan; 4. pemantauan (observasi); 5. perenungan (refleksi) pada setiap tindakan yang dilakukan; 6 . penyimpulan hasil berupa pengertian dan pemahaman (evaluasi). Mengacu pada teori tentang penelitian tindakan kelas, maka rancangan penelitian disusun menggunakan prosedur sebagai berikut:

\section{Dialog awal}

Digunakan untuk merumuskan permasalahan kesulitan belajar siswa kelas XI Geomatika SMKN 2 Surakarta khususnya dalam materi fungsi dan fungsi inver.

\section{Perencanaan Tindakan}

Berdasarkan hasil dari dialog awal dan kesepakatan rekan kolaborasi tindakan yang akan dilakukan untuk meningkatkan hasil belajar siswa yaitu dengan menerapkan metode Think Pair Share dalam 
pembelajaran matematika khususnya memecahkan masalah Aljabar pada materi fungsi dan fungsi inver. Sebelum dilaksanakan tindakan, peneliti terlebih dahulu menyusun silabus yang digunakan sebagai pedoman dalam pembelajaran. Sedangkan rencana pembelajaran (RPP) disusun pada saat perencanaan pada masing-masing putaran. Indikasi yang menunjukkan bahwa siswa telah mampu memecahkan masalah aljabar adalah ditunjukkan oleh adanya penerapan konsep berfikir matematis dalam memecahkan masalah yakni 1) pemahaman masalah (understanding problem), 2) perencanaan (devising a plan), 3) pelaksanakan rencana penyelesaian masalah (carry-ingout the plan, dan 4) melakukan pengecekan penyelesaian (looking back) dan nilai yang diperoleh setiap dilakukan post test.

\section{Pelaksanaan Tindakan}

Pelaksanaan tindakan pembelajaran dengan menggunakan metode Think Pair Share adalah sebagai berikut :

\section{Tahap Perencanaan}

Membuat rencana tindakan yaitu pada Kompetensi Dasar fungsi dan fungsi inver. Perangkat pembelajaran disusun oleh peneliti dan divalidasi oleh validator ahli, yaitu berupa: a) rencana pelaksanaan pembelajaran, b) materi pembelajaran, c)lembar kerja siswa, dan d) tes hasil belajar.

Pada perencanaan ini, peneliti sekaligus bertindak sebagai pemberi tindakan dalam proses pembelajaran, sedangkan kegiatan pengamatan/observasi dilakukan oleh observer yaitu Ibu Dra. Anik Susilowati.

\section{Tahap Pelaksanaan}

Pelaksanaan tindakan siklus 1 dilaksanakan selama 2 kali pertemuan, dengan 1 kali pertemuan untuk proses pembelajaran dan 1 kali diadakan untuk tes hasil belajar siklus I. tahapan ini meliputi :

\section{Tahap Awal}

Terdiri dari kegiatan sebagai berikut : (1) memberi persepsi awal untuk mengantarkan siswa pada materi yang akan dipelajari yaitu tentang fungsi dan fungsi inver dengan memberikan contoh bentuk penjabaran matematik; (2). membagi siswa menjadi beberapa kelompok, tiap kelompok terdiri dari 24 siswa; (3) Guru menyampaikan secara sekilas tujuan yang hendak dicapai dalam pembelajaran melalui metode Think Pair Share (TPS).

\section{Tahap Inti Pembelajaran Think Pair Share (TPS).}

Tahap inti pembelajaran dengan metode Think Pair Share (TPS) terdiri dari kegiatan sebagai berikut : (1) Guru memberikan gambaran dalam memecahkan masalah dalam matematika secara klasikal,(2) guru memberikan soal fungsi dan fungsi inver pada tiap tiap kelompok, setiap materi dalam kelompok dibuat soal yang berbeda-beda; (3) mengkondisikan siswa dalam kelompok untuk belajar saintifik Mengamati, Menanya, Mengeksplorasi, Mengasosiasi, Mengkomunikasikan (5M) melalui metode Think Pair Share yaitu saling bertukar pikiran untuk menyelesaikan soal. (4) siswa dan guru bersama-sama membahas latihan soal tiap kelompok yang telah dikerjakan siswa dan menyamakan 
persepsi, guru melakukan refleksi pada siswa yang belum memahami metode Think Pair Share, sehingga membuat siswa lebih mudah memahami cara-cara memecahkan masalah matematika.

\section{Tahap Akhir}

Pada tahap akhir terdiri dari beberapa kegiatan antara lain : (1) Siswa dan guru melakukan refleksi dengan mereview apa yang telah dipelajari; (2) Guru melakukan refleksi pada siswa bahwa memecahkan masalah matematika dengan metode Think pair Share membuat siswa lebih mudah memahami pemecahan masalah matematika (3) Guru menugasi siswa di rumah untuk melakukan latihan memecahkan masalah dari soal fungsi dan fungsi inver.

\section{Observasi dan Monitoring.}

Pada tahap ini sebenarnya berjalan bersamaan dengan saat pengamatan dilakukan pada waktu tindakan sedang berjalan. Jadi keduanya berlangsung dalam waktu yang sama. Pada tahap ini peneliti melakukan pengamatan dan mencatat semua hal yang diperlukan dan terjadi selama tindakan berlangsung. Pengumpulan data ini dilakukan dengan menggunakan format observasi atau penilaian yang telah tersusun, termasuk juga pengamatan secara cermat pelaksanaan skenario tindakan dari waktu ke waktu serta dampaknya terhadap proses dan hasil belajar siswa. Data yang dikumpulkan dapat berupa data kuantitatif (hasil tes, kuis, presentasi, nilai tugas, dan lain-lain) atau data yang menggambarkan keaktifan siswa, antusias siswa, mutu diskusi yang dilakukan dan lain-lain. Berdasarkan data yang terkumpul tersebut kemudian dilakukan analisis dan refleksi terhadap tindakan yang telah dilakukan.

\section{Refleksi}

Tahap ini dimaksudkan untuk menguasai secara menyeluruh tindakan yang telah dilakukan, berdasarkan data yang terkumpul, kemudian dilakukan evaluasi guna menyempurnakan tindakan selanjutnya.

Refleksi ini mencakup analisis, sintesis, dan penilaian terhadap hasil pengamatan atas tindakan yang dilakukan. Jika terdapat masalah dalam proses refleksi maka dilakukan proses pengkajian ulang melalui siklus berikutnya yang meliputi: perencanaan ulang, tindakan ulang dan pengamatan ulang sehingga permasalah dapat teratasi.

\section{Evaluasi}

Kegiatan ini sebagai proses mengumpulkan, mengolah, dan menyajikan informasi sehingga bermanfaat untuk pengambilan keputusan tindakan. Diantara dialog, perencanaan, refleksi dan evaluasi merupakan proses yang terkait secara logis, sistematis, dan berkesinambungan. Evaluasi diarahkan pada penemuan bukti-bukti peningkatan hasil belajar siswa.

\section{Analisis Data}

Teknik analisis yang digunakan dalam penelitian ini adalah analisis deskriptif kualitatif karena analisis ini bertalian dengan uraian deskriptif tentang perkembangan proses pembelajaran. Teknik tersebut mencakup kegiatan mengungkap kelebihan dan kelemahan kinerja siswa dan guru dalam proses belajar mengajar. Hasil analisis tersebut nantinya akan digunakan sebagai dasar untuk 
menyusun perencanaan tindakan untuk tahap berikutnya. Selain analisis kritis, digunakan pula teknik analisis kualitatif model alur, meliputi: reduksi data, penyajian data, dan penarikan kesimpulan (Milles \& Huberman, 1989 dalam Zainal Aqib, 2008).

Reduksi data

Merupakan proses penyederhanaan yang dilakukan melalui seleksi, pengelompokan, dan pengorganisasian data mentah menjadi sebuah informasi yang bermakna. Data atau informasi yang relevan terkait langsung dengan pelaksanaan PTK yang diolah untuk bahan evaluasi.

\section{Penyajian data}

Penyajian data merupakan suatu upaya menampilkan data secara jelas dan mudah dipahami dalam bentuk paparan naratif, tabel, grafik, atau perwujudan lainnya yang dapat memberikan gambaran jelas tentang proses dan hasil tindakan yang dilakukan. Penyajian data dilakukan dalam rangka pemahaman terhadap sejumlah informasi yang memberi kemungkinan adanya penarikan kesimpulan.

\section{Penarikan kesimpulan}

Penarikan kesimpulan merupakan pengambilan intisari dari sajian data yang telah terorganisasikan dalam bentuk pernyataan atau kalimat singkat, padat dan bermakna. Penarikan kesimpulan ini dilakukan secara bertahap untuk memperoleh tingkat kepercayaan yang tinggi.

Data yang diperoleh dari post-test I, post-test II, lembar pengamatan untuk penilaian afektif siswa dianalisis secara kuantitatif. Perbandingan nilai rata-rata kelas antara post-test I dan post-test II dipergunakan untuk mengetahui adanya peningkatan hasil belajar siswa. Jika nilai rata-rata kelas pada post-test II lebih besar dari post-test I, maka terdapat peningkatan kemampuan siswa mampu memecahkan masalah aljabar khususnya pada fungsi dan fungsi inver dan hasil belajar matematika dengan diterapkannya model pembelajaran Think Pair Share.

\section{HASIL}

\section{Deskripsi Data Kondisi Awal}

Kemampuan pemecahan masalah Aljabar pada materi fungsi dan fungsi inver. Siswa dalam memecahkan masalah aljabar khususnya pada materi fungsi dan fungsi inver masih sangat rendah yakni $47,22 \%$ atau 17 siswa dari 36 siswa telah mampu memecahkan masalah dalam matematika sedangkan yang tidak mampu sebesar $52,7 \%$ atau 19 siswa dari 36 siswa.

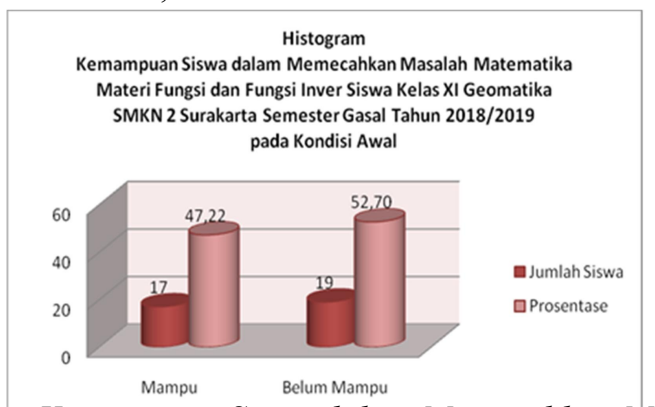

Gambar 1. Histogram Tingkat Kemampuan Siswa dalam Memecahkan Masalah matematika Materi Fungsi dan Fungsi Inver Siswa Kelas XI Geomatika SMKN 2 Surakarta pada Kondisi Awal 
Indikator dari rendahnya kemampuan pemecahan masalah aljabar tentang induksi matematika tersebut terlihat dalam beberapa aspek berikut : 1) siswa yang memahami masalah (understanding problem) sebesar 55\% atau 20 dari 36 siswa, 2) siswa yang mampu merencanakan (devising a plan), sebesar 44.44\%, atau 16 dari 36 siswa, 3) siswa yang mampu melaksanakan rencana penyelesaian masalah (carry-ingout the plan) sebesar 47\%, atau 17 dari 36 siswa, dan 4) siswa yang mampu melakukan pengecekan penyelesaian (looking back) sebesar 44\% atau 16 siswa dari 36.

\section{Deskripsi Data Siklus 1}

\section{Pelaksanaan tindakan siklus I}

Tindakan siklus I pada pertemuan pertama dilaksanakan hari Kamis, 2 Agustus 2018, pada jam ke 3,4 yaitu dimulai pukul 08.30 - 10.00 WIB. Jumlah siswa yang hadir sebanyak 36 siswa. Dalam pelaksanaan tindakan, peneliti berperan sekaligus sebagai guru, sedangkan teman sejawat ibu Dra. Ani berperan sebagai observer. Sebelum melaksanakan tindakan terlebih dahulu menyusun Rencana Pembelajaran. Pembelajaran yang akan dilaksanakan berpedoman pada rencana pembelajaran selengkapnya dapat di lihat pada lampiran, secara ringkas sebagai berikut : Pada kegiatan awal setelah guru memasuki ruangan, Terdiri dari kegiatan sebagai berikut : 1) memberi persepsi awal untuk mengantarkan siswa pada materi yang akan dipelajari yaitu tentang Fungsi dan Fungsi Inver dengan memberikan contoh bentuk penjabaran matematik; 2). membagi siswa menjadi beberapa kelompok, tiap kelompok terdiri dari 2-4 siswa; 3) Guru menyampaikan secara sekilas tujuan yang hendak dicapai dalam pembelajaran melalui metode Think Pair Share (TPS).

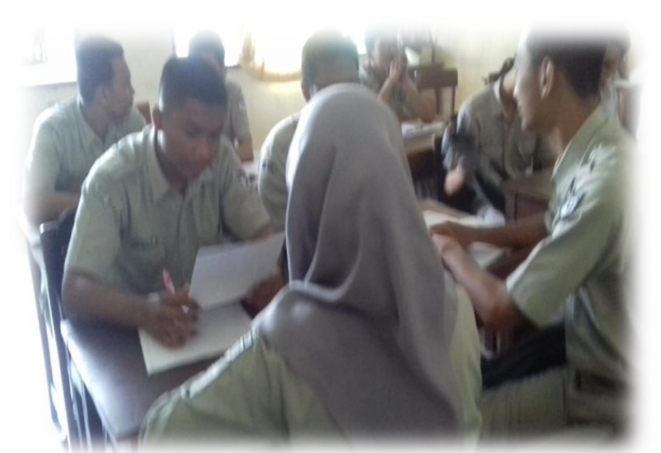

Gambar 2. Siswa saling bertukar informasi di kelompoknya melalui Think Pair Share

Tahap selanjutnya yaitu tahap inti, Guru memberikan gambaran dalam memecahkan masalah dalam matematika secara klasikal, 2) guru memberikan soal Fungsi dan Fungsi Inver pada tiap tiap kelompok, setiap materi dalam kelompok dibuat soal yang berbeda-beda; 3) mengkondisikan siswa dalam kelompok untuk belajar saintifik Mengamati, Menanya, Mengeksplorasi, Mengasosiasi, Mengkomunikasikan (5M) melalui metode Think Pair Share yaitu saling bertukar pikiran untuk menyelesaikan soal. Selama proses pelaksanaan pembelajaran berlangsung guru berkeliling sambil mengamati dan menilai keaktifan siswa dalam belajar tersebut 4) siswa dan guru bersama-sama 
membahas latihan soal tiap kelompok yang telah dikerjakan siswa dan menyamakan persepsi, guru melakukan refleksi pada siswa yang belum memahami metode Think Pair Share, sehingga membuat siswa lebih mudah memahami cara-cara memecahkan masalah matematika. Pada tahap akhir siswa dan guru bersama-sama membahas latihan pemecahan masalah matematika yang telah dikerjakan siswa dan menyamakan persepsi.

Selanjutnya guru melakukan evaluasi dan refleksi pada penerapan metode Think Pair Share serta mengulas pelaksanaannya, sehingga membuat siswa lebih memahami metode tersebut.

\section{Hasil Tindakan Kelas Siklus I}

Observasi dan Monitoring Tindakan I

Observasi dan monitoring yang dilakukan

oleh peneliti dan teman sejawat ditujukan pada semua komponen pendukung dalam proses pembelajaran yaitu tindak belajar siswa, dan tindak mengajar guru, adapun hasilnya sebagai berikut :

Observasi pada pertemuan pertama

\section{Tindak belajar siswa}

Observasi pada tiap-tiap kelompok pada Siklus I pertemuan pertama terdiri atas perhatian kelompok selama apersepsi, partisipasi kelompok dalam mengikuti pelajaran, keaktifan kelompok dalam proses tahapan memecahkan masalah matematika induksi matematika. Hasil pengamatan tentang kemampuan siswa dalam memecahkan masalah matematika di peroleh hasil bahwa siswa belum sepenuhnya mampu memecahkan masalah secara urut sebab siswa masih berpatokan cara yang lama yang mereka lakukan yakni cara cepat, demikian pula pada partisipasi kelompok dalam pelaksanaan Think Pair Share juga masih minim terlihat yang bekerja masih didominasi siswa tertentu saja.

\section{Tindak mengajar guru}

Guru telah membagikan lembar kerja siswa (LKS) pada setiap siswa untuk dikerjakan secara individu maupun kelompok berpasangan, selama proses pembelajaran guru berkeliling memandu dan mengarahkan siswa dalam pembelajaran Think Pair Share, Guru memfasilitasi proses tahapan pemecahan masalah dari kelompok yang di rasa membutuhkan panduan serta memandu presentasi hasil pembelajaran Think Pair Share di depan kelas.

\section{Observasi pada pertemuan kedua}

\section{Tindak belajar siswa}

Tindak belajar siswa sudah mengalami peningkatan setelah guru memberikan motivasi dan arahan terkait pengajaran yang diberikan, hal tersebut terlihat banyaknya siswa yang aktif mengikuti tahapan pembelajaran Think Pair Share sejak dimulai apersepsi hingga akhir kegiatan.

\section{Tindak mengajar guru}

Guru senantiasa memotivasi siswa, membimbing, mengarahkan kegiatan Think Pair Share namun pengaturan waktu belum efektif, masih banyak waktu yang terbuang. Observasi hasil tindakan Think Pair Share terhadap pemecahan masalah matematika pada materi Fungsi dan Fungsi Inver pada tiap tiap kelompok selama tindakan pada tatap muka pertama dan kedua. Perolehan skor kemampuan 
dalam memecahkan masalah Induksi Matematika secara kelompok melalui Think Pair Share selama Siklus I baik pada pertemuan pertama dan kedua didapatkan hasil bahwa : kemampuan memecahkan masalah aljabar khususnya pada materi Fungsi dan Fungsi Inver masih kategori rendah dan belum memenuhi target indikator yang ditentukan yakni siswa yang mampu memecahkan masalah secara umum baru $64 \%$ atau 23 siswa dari 36 siswa, sedangkan yang belum mampu masih sebesar $36 \%$ atau 13 siswa dari 36 siswa.

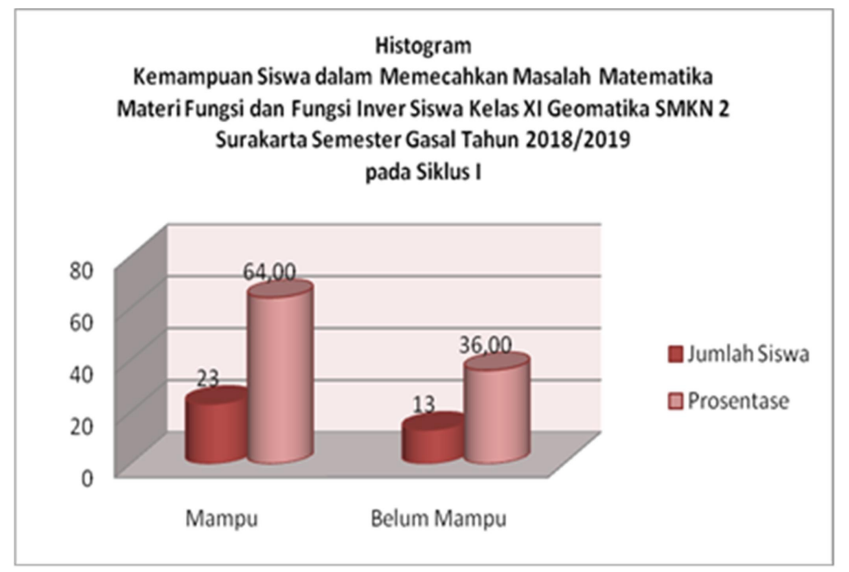

Gambar 4. Histogram Tingkat Kemampuan Siswa dalam Memecahkan Masalah Matematika Materi Fungsi dan Fungsi Inver Siswa Kelas XI Geomatika SMKN 2 Surakarta Tahun Pelajaran 2018/2019 Siklus I

Secara rinci indikator dari rendahnya kemampuan pemecahan masalah aljabar tentang Fungsi dan Fungsi Inver tersebut terlihat dalam beberapa aspek berikut : (a) siswa yang memahami masalah (understanding problem) sebesar 66.7\% atau 24 dari 36 siswa, (b) siswa yang mampu merencanakan (devising a plan), sebesar 58.3\%, atau 21 dari 36 siswa, (c) siswa yang mampu melaksanakan rencana penyelesaian masalah (carry-ingout the plan) sebesar 55\%, atau 20 dari 36 siswa, dan (d) siswa yang mampu melakukan pengecekan penyelesaian (looking back) sebesar 58.3\% atau 21 siswa dari 36 . Kategori kemampuan siswa dalam memecahkan masalah matematika di ukur dari perolehan skor keempat tahapan dalam memecahkan masalah yaitu, siswa telah mampu memahami masalah, merencanakan, melaksanakan rencana penyelesaian masalah, serta melakukan kembali pengecekan penyelesaian dengan skor maksimal.

\section{Refleksi terhadap tindakan kelas siklus I}

Refleksi tindakan kelas siklus I dilaksanakan setelah pelaksanaan tindakan kelas siklus I. kegiatan ini mendiskusikan hasil observasi tindakan kelas yang telah dilakukan. Berdasarkan hasil observasi tindakan kelas siklus I, terlihat bahwa proses pembelajaran dengan metode Think Pair Share dalam siklus I belum sesuai yang diharapkan dan belum bisa mencapai target indikator kinerja. Oleh karena perlu banyak pembenahan terutama pada komponen siswa, guru, dan metode pembelajaran sehingga dalam kegiatan belajar mengajar siswa dapat memahami materi pelajaran secara optimal dan menghasilkan capaian target kinerja sesuai harapan. 
Dari kegiatan refleksi ini, diperoleh beberapa hal yang dapat dicatat sebagai masukan untuk perbaikan pada tindakan selanjutnya yaitu: a). Masih ada siswa yang kurang aktif dalam belajar dan bekerjasama secara berkolompok bahkan bercerita dengan temannya walaupun ditegur karena tidak memperhatikan pelajaran. b). Dalam proses pembelajaran masih banyak siswa yang kurang menyerap materi pelajaran. c). Pada saat pembagian kelompok suasana kelas sangat ribut dan ramai. Hal ini dapat terlihat siswa mula-mula kurang bisa menerima pembagian kelompok secara heterogen. d).

Pada saat berpasangan masih banyak Siswa yang ragu dan kurang percaya diri dalam mengemukakan pendapatnya kepada siswa lain terutama siswa yang memiliki kemampuan rendah. e).

Dalam proses pembelajaran masih banyak siswa yang melakukan aktivitas lain diluar pembelajaran.hal ini bisa terlihat pada saat siswa berdiskusi dengan teman kelompoknya. Kekurangan dari aspek guru. a). Guru belum menjelaskan materi secara sistematis sehingga siswa kurang menyerap materi pelajaran. b). Dalam mengerjakan LKS Secara mandiri guru kurang merata dalam membimbing siswa. c). Guru kurang membimbing seluruh kelompok dalam kegiatan diskusi secara maksimal baik dalam saat siswa berpasangan maupun berbagi dengan keseluruhan kelas. d). Guru tidak menunjuk beberapa siswa untuk memberikan tanggapan pada saat presentase sehingga diskusi kurang aktif. e). Waktu pembelajaran tidak sesuai dengan yang direncanakan dikarenakan guru kurang mampu mengelola waktu secara efisien.

\section{Evaluasi terhadap tindakan kelas siklus I}

Hasil observasi dan refleksi pada tindakan kelas siklus I dievaluasi peneliti dengan guru teman sejawat. Evaluasi ini, diharapkan dapat mengatasi kekurangan dan menyelesaikan permasalahan yang terdapat pada siklus I. Solusi tindakan tersebut adalah : 1). Pemberian motivasi dan perhatian agar siswa dapat berperan secara aktif melakukan kerjasama kelompok agar lebih memahami materi Induksi Matematika dan siswa lebih berani mengemukakan pendapat. 2). Menjelaskan materi secara sistematis agar lebih mudah dipahami dan diserap oleh siswa. 3). Membimbing siswa /kelompok dalam berdiskusi agar diskusi lebih terarah. 4). Guru harus memperhatikan pengelolaan kelas agar siswa tidak mengerjakan aktivitas lain dalam proses pembelajaran. 5). Menunjuk beberapa siswa untuk memberikan tanggapan pada saat presentasi kelompok agar diskusi lebih hidup dan dapat menyamakan persepsi antara siswa yang satu dan yang lainnya. 6). Guru hendaknya dapat memperhatikan dan mengelolah waktu secara efisien, agar di dalam melaksanakan keseluruhan rencana pembelajaran dapat dilaksanakan dengan baik.

Kesimpulan yang diperoleh dari masalah-masalah yang ditemukan dalam siklus I ini, peneliti berusaha untuk mengadakan perbaikan dengan harapan agar siklus ke II jauh lebih baik daripada siklus sebelumnya.

\section{Deskripsi data Siklus II}

Pembelajaran tindakan kelas siklus II dilaksanakan berdasarkan hasil revisi dan Rencana Perbaikan Pembelajaran (RPP) yang telah dibuat yang dilaksanakan selama 2 jam pelajaran (90 menit) dengan materi ajar tentang Pemecahan masalah Fungsi dan Fungsi Inver. Pembelajaran 
dilaksanakan dengan menerapkan metode pembelajaran Thaink Pair Share seperti pada tindakan kelas siklus I.

\section{Perencanaan Tindakan II}

Tahap perencanaan ini merupakan perbaikan dari hasil refleksi yang kurang pada siklus sebelumnya. Siklus kedua ini dilaksanakan dengan langkah-langkah perbaikan dengan mengidentifikasi dan merumuskan masalah berdasarkan hasil analisa refleksi siklus pertama seperti : 1). Penyusunan RPP Matematika siswa kelas XI SMKN 2 Surakarta melalui model pembelajaran kooperatif tipe Think Pair Share harus sesuai dengan alokasi waktu yang digunakan serta mempersiapkan sub tema lanjutan dari siklus sebelumnya. 2). Menyusun format observasi guru dan observasi sikap siswa. 3). Menyusun LKS dan menyiapkan sumber belajar. 4). Membuat tes penilaian hasil belajar Matematika berdasarkan materi yang diajarkan melalui pembelajaran kooperatif tipe Think Pair Share.

\section{Pelaksanaan Tindakan Siklus II}

Pelaksanaan tindakan pada siklus kedua sama dengan siklus sebelumnya dan mengacu pada kekurangan yang terjadi. Pelaksanaan tindakan pada siklus pertama dilaksanakan selama 2 kali pertemuan, 1 kali pertemuan untuk proses pembelajaran dan 1 kali untuk tes siklus. Pelaksanaan tindakan Siklus II pertemuan pertama dilaksanakan tanggal 6 September 2018. Dalam pelaksanaan tindakan siklus II ini tahap pertama siswa dibagi menjadi 9 kelompok.Pelaksanaan tindakan Siklus II pertemuan kedua dilaksanakan tanggal 13 September 2018.

Uraian proses pembelajaran siklus II, adalah sebagai berikut :

\section{Mengidentifikasi Topik Dan Pembentukan Kelompok}

Pembagian kelompok didasarkan pada tempat duduk yang diurutkan dan dibagi rata antara putra dan putri, sehingga per kelompok antara putra dan putri terbagi rata. Di kelas XI Geomatika berjumlah 36 siswa pada tahap ini dibagi menjadi 9 kelompok, yang mana pada setiap kelompok terdiri dari 4 siswa. Topik yang disikusikan yaitu tentang pemecahan masalah matematika materi Fungsi dan Fungsi Inver yang meliputi memahami masalah, merencanakan, melaksanakan rencana penyelesaian masalah, serta melakukan kembali pengecekan penyelesaian dengan skor maksimal.

\section{Merencanakan Tugas Belajar}

Pada tahap ini setiap anggota kelompok dituntut untuk pemecahan masalah matematika materi Fungsi dan Fungsi Inver yang mereka terima, kemudian melakukan diskusi untuk memahami masalah, merencanakan, melaksanakan rencana penyelesaian masalah, serta melakukan kembali pengecekan penyelesaian. Dalam diskusi kelompok Think Pair Share ini, peneliti telah menyediakan lembar kerja siswa soal yang berisi soal Fungsi dan Fungsi Inver. 


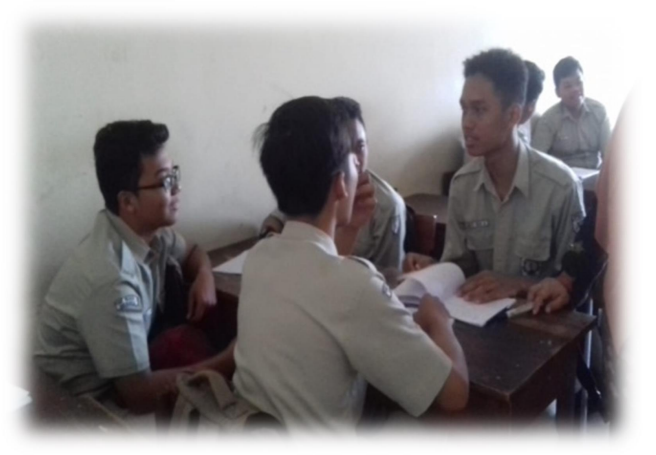

Gambar 5. Foto aktivitas siswa pada siklus II, dalam Think Pair Share

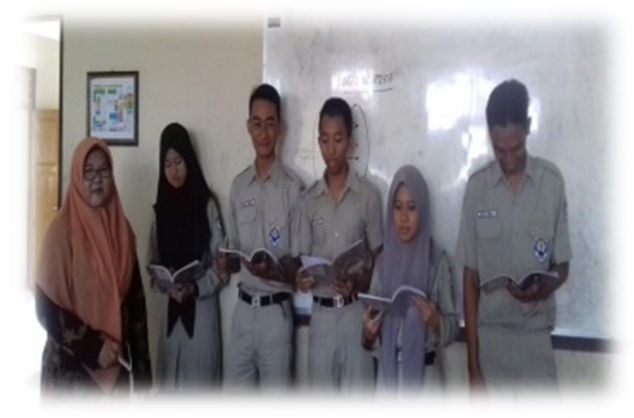

Gambar 6. Siswa saat presentasi memecahkan masalah matematika melalui Think Pair Share pada siklus II

\section{Hasil Tindakan Kelas Siklus II}

Observasi dan monitoring tindakan kelas siklus II

Tindak mengajar

Guru telah melaksanakan pembelajaran dengan baik sesuai dengan langkah-langkah model-model pembelajaran kooperatif tipe Think Pair Share (TPS), guru telah memberi motivasi siswa untuk belajar dan bekerja sama secara berkelompok. Guru telah mengatur waktu pembelajaran secara efektif dan efisien.

Tindak belajar

Perhatian kelompok selama apersepsi tampak siswa semakin mantab dan antusias, begitu pula pada kegiatan partisipasi kelompok siswa sudah menunjukkan partisipasi tidak malas-malasan dalam berdiskusi dan melaksanakan tahapan pemecahan masalah matematika, pada saat mengerjakan LKS atau tugas yang diberikan guru dalam kelompok suasana kelas tampak lebih tenang, hampir semua siswa aktif dalam kegiatan pembelajaran dan mampu berdikusi dengan baik.

Kemampuan memecahkan masalah matematika siswa

Hasil monitoring terhadap kemampuan siswa dalam memecahkan masalah matematika terlihat bahwa : kemampuan memecahkan masalah aljabar khususnya pada materi Fungsi dan Fungsi Inver telah mengalami peningkatan dan sudah memenuhi target indikator yang ditentukan yakni siswa yang 
mampu memecahkan masalah secara umum sebesar $85 \%$ atau 31 siswa dari 36 siswa, sedangkan yang belum mampu masih sebesar $13.8 \%$ atau 5 siswa dari 36 siswa.

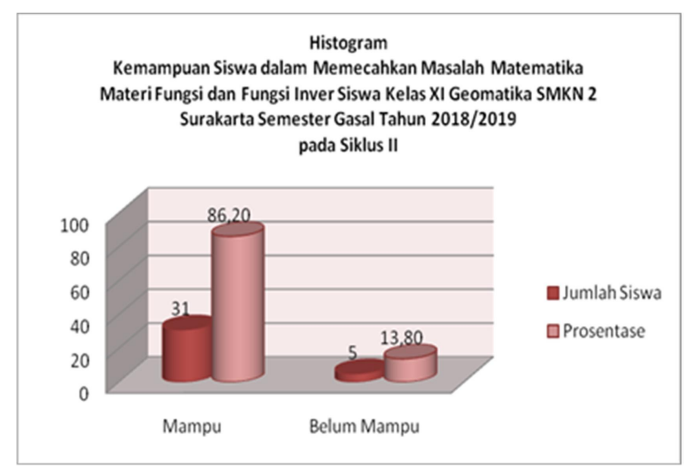

Gambar 7. Histogram Tingkat Kemampuan Siswa dalam Memecahkan Masalah Matematika Materi Fungsi dan Fungsi Inver Siswa Kelas XI Geomatika SMKN 2 Surakarta Tahun Pelajaran 2018/2019 Siklus II

Secara rinci indikator dari kemampuan pemecahan masalah aljabar tentang Fungsi dan Fungsi Inver tersebut terlihat dalam beberapa aspek berikut : 1) siswa yang memahami masalah (understanding problem) sebesar $89 \%$ atau 32 dari 36 siswa, 2) siswa yang mampu merencanakan (devising a plan), sebesar 90\%, atau 33 dari 36 siswa, 3) siswa yang mampu melaksanakan rencana penyelesaian masalah (carry-ingout the plan) sebesar 83\%, atau 30 dari 36 siswa, dan 4) siswa yang mampu melakukan pengecekan penyelesaian (looking back) sebesar 80.5\% atau 29 siswa dari 36.

Refleksi Terhadap Tindakan Kelas Siklus II

Refleksi tindakan kelas siklus II dilakukan setelah pelaksanaan tindakan siklus II. Kegiatan ini mendiskusikan hasil tindakan kelas siklus II, terlihat bahwa : a). Guru mampu melaksanakan pembelajaran dengan baik sesuai dengan langkah-langkah model-model pembelajaran kooperatif tipe Think Pair Share (TPS). b). Semua siswa telah termotivasi dalam belajar dan bekerja sama secara berkelompok. Hampir semua siswa aktif dalam kegiatan pembelajaran dan mampu berdikusi dengan baik. c). Pada saat mengerjakan LKS atau tugas yang diberikan guru dalam kelompok suasana kelas tampak lebih tenang. d). Waktu pembelajaran berlangsung sesuai dengan yang direncanakan. Guru sudah mampu mengelola waktu secara efisien.

\section{Evaluasi Terhadap Tindakan Kelas Siklus II}

Menyikapi hasil refleksi siklus II dan setelah mengamati berbagai kekurangan dan kemajuan belajar mengajar bahwa sebagian besar kekurangan yang ditemukan pada siklus I dari $64 \%$ mengalami peningkatan pada siklus II menjadi $85 \%$ sehingga dapat dikatakan penelitian ini berhasil karena dapat meningkatkan kemampuan siswa dalam memecahkan masalah matematika materi Fungsi dan Fungsi Inver setelah diterapkan model pembelajaran kooperatif Think Pair Share (TPS). 


\section{KESIMPULAN}

Penerapan metode pembelajaran Think Pair Share secara signifikan dapat meningkatkan kemampuan siswa dalam pemecahan masalah matematika pada materi Fungsi dan Fungsi Inver Siswa kelas XI Geomatika SMKN 2 Surakarta. Kemampuan siswa dalam pemecahan masalah matematika pada materi Fungsi dan Fungsi Inver pada kondisi awal sebelum tindakan persentase kemampuannya berada pada kategori rendah yaitu $47.22 \%$ dan pada siklus I mengalami peningkatan dengan tingkat kemampuan sedang yaitu 64\% dan pada siklus II kemampuan siswa berada pada kategori tinggi yaitu $85 \%$. Peningkatan kemampuan siswa dalam pemecahan masalah matematika sangat signifikan yaitu sebesar $37,78 \%$ dari kondisi awal.

\section{DAFTAR PUSTAKA}

Bell. 1981. Teaching and Learning Mathematichs. Dubuque Lowo: Win C. Broom Company Publiser.

Depdiknas. 2002. Teori-Teori Perkembangan Kognitif dan Proses Pembelajaran yang Relevan untuk Pembelajaran Matematika. Pelatihan Terintegrasi berbasis kompetensi.

Gulo, W. (2002). Strategi Belajar Mengajar. Jakarta : PT. Grasindo

Huda, Miftahul. 2013. Model-Model Pengajaran dan Pembelajaran.Yogyakarta: Pustaka Pelajar Celeban Timur.

Hudoyo, Herman 2001. Mengembangkan Kurikulum dan Pembelajaran Matematika. Jurusan Pendidikan Matematika. FGEOMATIKA UM Malang.

Hudoyo, Herman.1990. Mengajar Belajar Matematika. LPTK Jakarta: Depdikbud.

Polya, G. 1973. How to Solve it, Second Edition. Princeton. New Jersey Princeton University Press.

Russefendi, 1988. Membantu Guru Mengembangkan Kompetensinya dalam pengajaran matematika untuk meningkatkan CBSA. Bandung: Tarsito.

Soleh, Mohammad. 1998. Pokok-pokok Pengajaran Matematika Sekolah. Jakarta: Depdikbud.

Solso. R. Robert, Maclin. H. Otto, Maclin. Kimberly. M. 2007. Psikologi Kognitif. Terjemahan Penerbit Erlangga, Jakarta:Erlangga

Trianto. 2007. Model-Model Pembelajaran Inovatif Berorentasi Kontruktivistik. Jakarta: Prestasi Pustaka.

Upu, Hamzah. 2003. Pengajuan Masalah dan Problem Solving dalam Pembelajaran Matematika. (Pegangan Untuk Guru, Siswa PPS, Calon Guru, \& Guru Matematika. 